腹部打撲を認めない胃破裂の 1 例

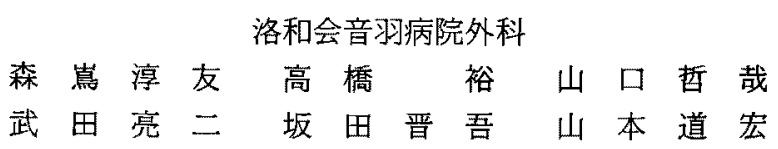

33歳, 男性. 多量飲食後車で帰宅中, 酒気帯び運転にて自損事故を起こし救急搬送さ れた。搬入時，呼吸時胸痛，腹部鈍痛を訴えたが悪心嘔吐はなかった。視診上，腹部に 皮下血腫はなかった，緊急検查では左多発肋骨骨折を認め，血気胸はないが軽度呼吸困 難あり呼吸器科に入院となった. 3 時間後, 腹部の自発痛を訴え腹部板状硬, 反跳痛を 認めた。腹部 CT を再検したところ腹腔内遊離ガス像認め，胃小彎側から胃内容物の漏 出が疑われ，外傷性胃破裂の診断にて緊急開腹術を施行した．開腹すると胃前庭部小彎 前壁に I cm の胃壁完全断裂を認め, 胃内容物が漏出していた.さらに同部位から噴門側 に向かって筋層, 粘膜が $8 \mathrm{~cm}$ 断裂していた。他の腹腔内臟器には損傷はなかった. 胃壁 損伤部辺縁を切除し縫合閉鎖した。術後経過は良好で術後14日目で退院した。腹部打撲 痕がなく, 腹腔内の他藏器損傷も伴わない単独の外傷性胃破裂は㓙好て特異で稀である ため，破裂のメカニズムについて文献的考察を行い報告する。

索引用語：鈍的外力，外傷性胃破裂，胃小彎

\section{緒言}

鈍的外力による外符性消化管穿孔は主に小腸に認め られるが，胃破裂に関する報告は非常に少ない．今回 われわれ腹部打撲を認めない興味ある機序による外 傷性胃破裂の 1 例を経験したので報告する。

$$
\text { 症例 }
$$

患者：33歳, 男性.

主訴：呼吸時胸痛, 腹部鈍痛.

既往歴: 肝機能障害, 高尿酸血症, 高脂血症.

家族歴：特記すべき事項なし。

既往歴：平成15年 7 月19日午前 4 時まで大量飲食 後, 自家用車を運転し㷌宅する際, 国道の中央分離帯 に衝突し当院救急外来に搬送された，事故当時シート ベルトはしておらず，エアバックが作動していた．搬 入時, 呼吸時胸痛と腹部全体の軽度鈯痛を訴えていた。 腹部に関しては打撲していないと話した. 胸部単純撮 影で左下部胁骨の多発骨折認め, 右横隔膜下には free airがなく, 呼吸器科に入院となった。

2004年 1 月13日受付 2004年 3 月19日採用 〈所属施設住所〉

于 $607-8062$ 京都市山科区音羽珍事町 2
入院時現症：意識清明，循環動態および呼吸状態安 定し呼吸時胸痛あるも呼吸音は正常であった。腹痛は 軽度で, 胸腹部とも皮下出血㹥認めなかった.

入院時検查成績: GOT 76IU/1, GPT 45IU/1, LDH $617 \mathrm{IU} / 1$ の軽度上昇と WBC $10400 / \mu 1$ と軽度上昇を認 めた(表 1 )。その他の検査所見は特に異常を認めなか つた.

頭部 CT：出血性病変など異常所見は認めなかっ た。

胸部 CT : 左第 7，10肋骨骨折を認めたが肺野には 血気胸など異常を認めなかった。

腹部 CT (入院直後)：free air など異常所見は認め ず, 肝藏, 脾臓, 满臓, 腎臓にも葴器損傷認めなかっ た。

入院後, 約 3 時間経過したのち, 腹部全体の疼痛を 訴えるようになったため当科受診となった。そての時点 で腹部は触診上，板状硬であり反跳痛も認め，沉発性 腹膜炎が疑われた．腹部CT を再検し以下の所見を得 た。

再検腹部 CT：腹腔内に血性腹水と考えられる夜体 盼留像㧍よび肝前面と胃小潄側周囲に free air 認め た．さらに胃小彎側から胃内容の漏出と思われる画像 
表 1 入院時血液生化学検查結果

\begin{tabular}{|c|c|c|}
\hline GOT & 76 & $\mathrm{IU} / \mathrm{I}$ \\
\hline GPT & 45 & IU/1 \\
\hline ALP & 234 & IU/1 \\
\hline$\gamma$-GTP & 53 & $\mathrm{IU} / 1$ \\
\hline $\mathrm{CHE}$ & 312 & $\mathrm{IU} / \mathrm{l}$ \\
\hline LDH & 617 & $\mathrm{IU} / 1$ \\
\hline BUN & 13.8 & $\mathrm{mg} / \mathrm{dl}$ \\
\hline CRE & 1.0 & $\mathrm{mg} / \mathrm{dl}$ \\
\hline UA & 9.5 & $\mathrm{mg} / \mathrm{dl}$ \\
\hline 血糖 & 133 & $\mathrm{mg} / \mathrm{dl}$ \\
\hline $\mathrm{T}-\mathrm{CHO}$ & 200 & $\mathrm{mg} / \mathrm{dl}$ \\
\hline TG & 442 & $\mathrm{mg} / \mathrm{dl}$ \\
\hline CPK & 108 & $\mathrm{IU} / \mathrm{l}$ \\
\hline CRP & 0.27 & $\mathrm{mg} / \mathrm{dl}$ \\
\hline 白血球 & 10.4 & $\times 10^{3} / \mu 1$ \\
\hline $\mathrm{Hb}$ & 15.0 & $\mathrm{~g} / \mathrm{dl}$ \\
\hline $\mathrm{Ht}$ & 42.6 & $\%$ \\
\hline 血小板 & 279 & $\times 10^{3} / \mu 1$ \\
\hline
\end{tabular}

所見も認められた (図 1，2：矢印).

以上の所見により胃破裂による穿孔性腹膜炎と診断 し緊急開腹術を施行した。

手術所見：上腹部正中切開にて開腹した。開腹と同 時に, 胃小彎から大量の食物残渣の流出を確認し得た。 食物残渣流出部は胃角部小彎の $1 \mathrm{~cm}$ 大の胃壁全層破 裂孔であった。さらに破裂孔から連続して胃前壁に噴 門側へ向かって小彎側に浻った約 $8 \mathrm{~cm} の$ 線状の墏膜 下出血が認められた。この獎膜を切開すると直下の粘 膜, 筋層が完全に断裂していた(図 3，4).また, 破 裂部の四横指大彎側前壁にも漿膜損傷部を認めた。

盲垶を開放し，胃後壁の損傷の有無を確認したが胃 後壁には異常は認めなかった. 一方, 破裂部周囲の胃 粘膜には潰瘍などの病変の痕跡はなく健常胃壁の外傷 性破裂と診断した. 破裂した小彎側を中心に動静脈を 処理し損傷部辺縁の胃壁を約 $1 \mathrm{~cm}$ 切除し, 破裂した 胃壁を Albert-Lembert 縫合で 2 層縫合閉鎖した（図 5 ). 腹腔内を十分洗浄後, ドレーン留置し閉腹した. 術後経過：術後経過良好であり第 7 病日に胃透視を 施行し縫合不全や通過障害がないことを確認後, 食事 開始し14病日に退院した。

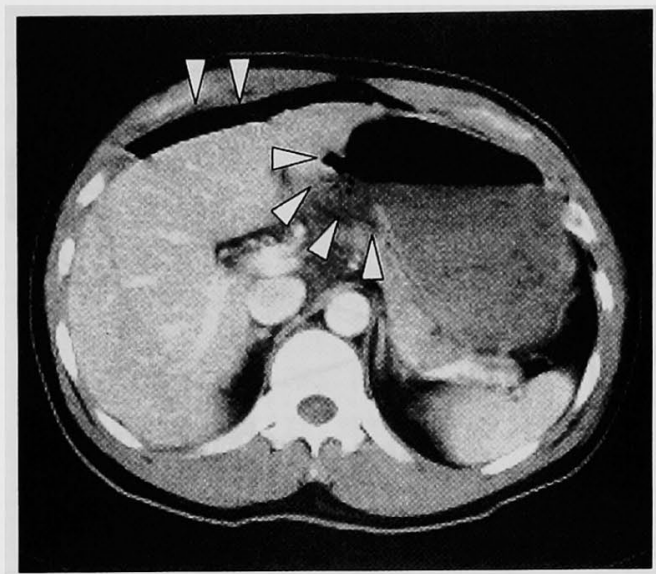

図 1 腹部 CT 検查 : 肝前面と胃小留側に free air 認めた (矢印).

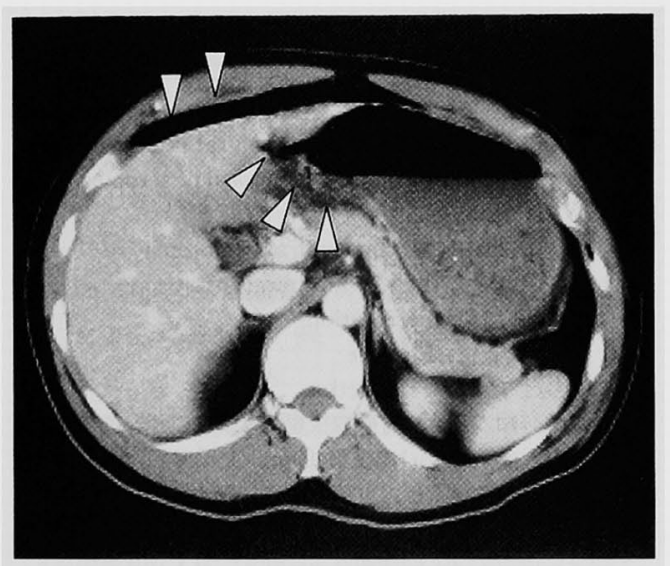

図 2 腹部 CT 検查：胃小警側から食物残渣の露出を認 めた。

\section{考察}

外傷性消化管穿孔は小腸で発生することが多く，今 回われわれが経験した合併臓器損傷を認めない単独の 外傷性胃破裂は非常に稀である. 欧米では ${ }^{13}$ 鈍的外力 による胃破裂は鈍的腹部外傷の $0.9 \sim 4.7 \%$ と言われて おり，本邦においても鈴木ら は $0 \sim 1.9 \%$ と報告しており総じて 1 〜 $2 \%$ 程度であ ると考えられる. 原因としては, 交通事故が最も多く, 中でもハンドル外傷やシートベルト外傷 ${ }^{4}$ が多いとさ れている(5)6). 交通事故以外では，狭圧事故(重量物間 に挟まれる事故 $)^{7)}$, CPR (心肺蘇生法 $)^{8)}$, Heimlich 法 (気道閉塞時の救命法) ${ }^{9}$ などで発生が報告されている. 


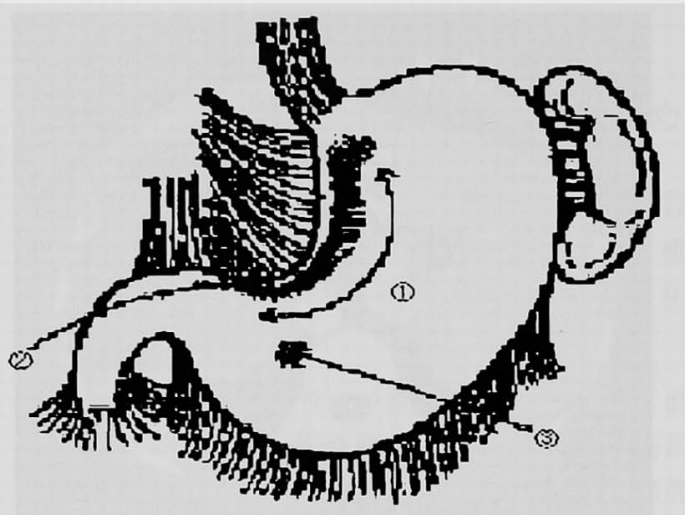

図 3 開腹時所見

(1) $8 \mathrm{~cm}$ の粘膜・筋層断裂部 ( I b ( M, Ant))

(2) $1 \mathrm{~cm}$ の全層断裂部 [IIb (A, Ant)]

(3)獎膜, 一部筋層損傷 ( I a (A, Ant) )

(胃損傷分類〈表 2 〉)

\section{表 2 胃損傷分類}

I 型 非全層性損傷Non-transmural injury

a. 整膜-槳膜筋層裂傷 Serosal or seromuscular tear

b. 壁内血腫 Intramural hematoma

II 型 全層性損傷 Transmural injury
a. 穿孔 Perforation
b. 破裂 Rapture
c. 離断 Transection

部位分類：部位は胃癌取扱規約に準じC, M, Aて 表し, 前壁 (Ant), 後壁 (Post) に分ける. 二部 位にわたる場合は，主部位を先に記す。

引用:

日本外傷学会消化器損傷分類委員会 : 日本外傷学会消

化管損傷分類. 日外傷会誌 $13: 172-176,1999$

鈍的外力による胃損傷が少ない要因としては，胃が 1) 助骨弓に囲まれ解剖学的に守られた位置にあるこ と，2）可動性に富むこと，3）比較的管腔内が広い こと，4）筋層が他の消化管に比べて厚いことなどが 挙げられている゙.

Baker らは鈍的外力による管腔蔵器が損傷を受け る機序として, (1)外力による消化管内圧の急激な上昇 による破裂, (2)墜落, 衝突などで生じる「減速力 (deceleration)』による剪断応力, (3)腹壁と椎体との間での圧 迫の 3 つを考察している ${ }^{10)}$.

鈍的外力による胃破裂部位は一簓所であることが多



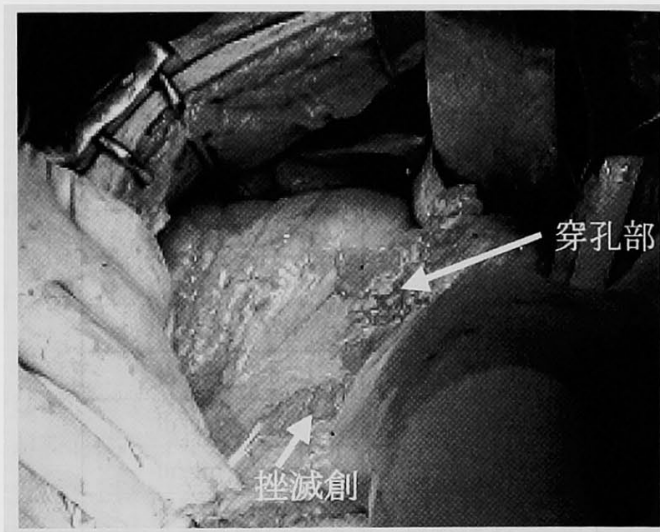

図 4 術中写真：穿孔部と挫滅創を認めた。

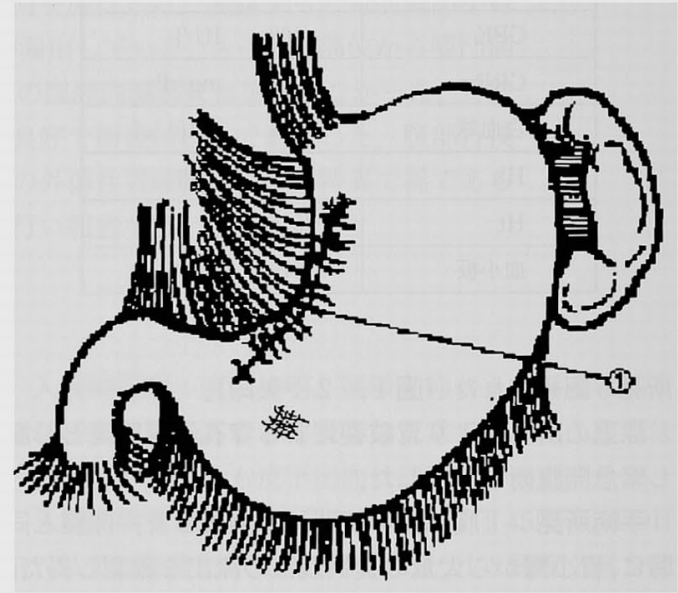

図 5 胃縫合後 (1) Albert-Lembert 縫合

とされる ${ }^{111}$.土原ら ${ }^{121}$ は,急激な胃内圧の上昇により破 裂する場合は, La place の法則 $\mathrm{T}=\mathrm{P} \cdot \mathrm{r} / 2 \mathrm{~h}$ ( $\mathrm{T}$ ：壁 張力, $\mathrm{P}$ : 内压, $\mathrm{r}$ ：半径, $\mathrm{h}$ ：壁の厚さ)に基づき曲率 半径の大きな大籃側に損傷が生じやすいと報告してい る.一方，衝突などによる急激な『減速力』が原因の 場合は，小網により比較的固定され移動性に乏しい小 彎側を中心にひねりが加わるため，胃小彎から前壁に 破裂が生じやすいという ${ }^{13)}$ ，また Frankel ら ${ }^{14)} は$ ，胃 小彎は粘膜の弾性が最も低く，筋層も薄いため，過度 の膨張により破裂を起こしやすいとしている，他方， 腹壁と椎体との間での圧迫による場合は, 膵や十二指 腸など隣接臓器に損傷が及びやすいと考えられてい る ${ }^{15)}$. 以上のように成因の違いにより損傷形態も異な ってくるため，こうした損傷部位や形態により破裂の 
機序を推定することは, ある程度可能であると思われ る.

鍵的胃破裂で食事摂取直後などの胃内容充満状態 (full stomach) を認めるのは59〜 77\%とされてお $\eta^{16)}$, full stomachにより胃壁が伸展され可動性を失 うことも罢破裂の重要な危険因子となると思われ る”.ささらに正常な状態では減圧機能を请えている噴 門部と幽門部は full stomachの状態ではこれらの機 能が破綻していると考えられ，罠内圧はさらに進す るものと推測される。具体的には内圧が約 $120 \sim 150$ $\mathrm{mmHg}$ を越えると胃破裂が生じるとされている".

本例ては，I）多量飲食後で胃が緊満し胃内正が上 昇していた状態であった，II）腹部を直接打撲してい ないと思われた，III）腹腔内の隣接䁍器の損傷は伴わ なかった，IV）胃小潛側前壁に破裂を認めた，ことか ら, 罞破裂の機序として, 衝突の際の急激な『減速力』 により胃の小彎側に益断広力が動いたことが原因とし て推察された。一方, air bag が作動していたこと，多 発肋骨骨折を生じていたことから，上半身が air bag に衝突して瞬間的に強い胸部压迫を生じたとも考えら れ，救急蘇生時 (CPR) に胃破裂㚙報告されているこ とと同様の機序による可能性も否定できないと思われ た.

外傷性胃破裂には合併損傷を伴う頻度が高く，心肺 停止やショック状態て搬入されることが多いと考えら れ，そのため䏴破翌として報告されない症例毛多数存 在すると思われる。 Louis ら ${ }^{18} に よ る と 1970$ 年代のよ うなCTがいまだ十分に普及していない時代では，臨 床所見と腹腔内試験穿刺による血性腹水の存在で試験 開腹を行っていたという. 現在では高速撮影可能な CT が開発され, 診断の中心的役割を担っている.しか しながら，初回 CT で free airなどの消化管穿孔を疑 わせる所見を認めない場合でも注意深い患者の観察を 通して CT 再検查を施行すると，われわれの症例のよ うに腹腔内遊雐ガスや腹水・腹腔内出血の出現を諮め る場合もあることが示されだ5).

外傷性胃破裂の死亡率は $7 \sim 12 \%$ と報告されてい $3^{17}$. 肝・脾・膵損傷, など臟器合併損傷による出血や ショック，そのたわの手術開始時間の遅延による腹腔 内の強度污染, それに伴った敗血症を呈している症例 では当然, 死亡率が高い，一方, 本例のように合併損 傷が無く手術までの時間が比較的短時間であった症例 では死亡率が低い.このため早期診断, 早期治療が重 要である13.
本例のように，腹部打撲を自覚的にも他賞的にも認 めない外傷患者の唁察に際し，特に飲食直後で胃が充 満状態であると思われる場合には，『減速力』という間 接的外力による筲破裂の可能性があることを念頭に置 き診断・治療にあたるべさであると思われた。

$$
\text { 文献 }
$$

1) Yajko RD, Seydel F, Trimble $C$ : Rupture of the stomach from blunt abdominal trauma. J Trauma 15: 177-183, 1975

2）鈴木正爾，綿貴 喆：鉱性外力に上る胃損傷の 数々相. 日救急医会誌 $3: 79-80,1976$

3）平山長一郎, 南 泰三, 平升 裕地：腹部鈍的外 鹪による胃㩫賃の経験. 蹦と研 $60: 170-172$, 1983

4）秋山裕人，新実紀二，堀沢 稳地：シートバルト 損傷による外佰性胃破裂の1例. 外科診療 12 ： $1625-1628,1992$

5）真栄城櫌夫, 真喜屋実佑, 藤村邦夫他：腹部外傷. 外科治療 $32: 201-207,1975$

6）森脇義弘，小澤幸弘，羽島慎㤑他：ハンドル外傷 による胃破裂，强偒の1救命例. 日腹部救急医 会誌 $18: 319-322,1998$

7）隅田英典, 丹波䇫朗, 角岡秀彦他：腹部鈍的外傷 による留破裂の1例。日腹部救急医会誌 15 ： $1285-1288,1995$

8）大柣穣治, 有馬 健, 斉藤 豪他：CPRに上る胃 破裂の 1 症例と本邦報告例の椧討. 日救急医会誌 $11: 66-70,2000$

9) Marilu TH: Gastric Rupture after the Heimlich Maneuver. J Trauma 40:159-160, 1966

10) Baker AR, Perry EP, Fossard DP : Traumatic rupture of the stomach due to a seat belt. Injury $17: 47-48,1986$

11) Sulaiman $A N$, Charles $M$ : Gastric rupture resulting from blunt abdominal trauma and requiring gastric resection. J Trauma $47: 410$ $-412,1999$

12）土原一哉, 桝谷博孝, 野手雅幸他：シートベルト 損傷による畋破裂の1例。日臨外会誌 $56: 1834$ $-1837,1995$

13) Siemens RA, Fulton RL: Gastric rupture as a result of blunt trauma. Am Surg 43:229-233, 1977

14) Frankel P: Untersuchungen zur Entstehung der 
sogenannten spontanen Magenruptur. Schrift $\mathrm{f}$ Klin Med $89: 113,1906$

15）福田直人，吉良邦彦，土用下和之他：腹部鈍的外 賃による胃破裂の 2 例. 救急医 $21: 612-614$, 1997

16) Semel L, Frittelli $G$ : Gastric rupture from blunt abdominal trauma. NY State J Med 81 : $938-$
939,1981

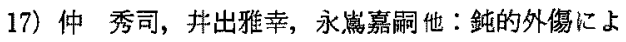
る胃被裂の2 例. 日救急医会関東誌 $16: 82-83$, 1995

18) Louis $A B$, John HM: Gastric rupture from blunt abdominal trauma. J Trauma $27: 887-$ 891,1987

\title{
A CASE OF GASTRIC RUPTURE DUE TO BLUNT INJURY
}

\author{
Atsutomo MORISHIMA, Hiroshi TAKAHASHI, Tetsuya YAMAGUCHI, \\ Ryouji TAKEDA, Shingo SAKATA and Michihiro YAMAMOTO \\ Department of Surgery, Rakuwakai Otowa Hospital
}

A 33-year-old man driving a car involved in a head-on collision just after a heavy meal and alcohol had not used a seatbelt, although an airbag activated correctly. On arrival at the emergency room, he reported respiratory chest pain and dull abdominal pain but no nausea or vomiting. No abdominal suggillation, (bruising or ecchymosis) was seen, and X-ray film and CT imaging of the chest and abdomen showed only multiple rib fractures. Physical examination when he reported abdominal pain 3 hours later on admission showed board-like abdominal rigidity. A second abdominal CT showed intraabdominal free air with suspected leakage of food from the stomach, necessitating emergency laparotomy was done under a diagnosis of gastric rupture. Laparotomy showed complete gastric wall tearing and food leakage from the perforation. No other intraabdominal organ injury was detected. The injured gastric wall was resected and the perforation sutured using the Albert-Lembert method. The man was discharged on postoperative day 14 without complications. Traumatic gastric perforation without other organ injury is very rare. We report this case together with considerations on the mechanism of solitary traumatic gastric perforation. 